\title{
Paliwa etanolowe w zastosowaniu do silników o zapłonie iskrowym
}

\begin{abstract}
W Unii Europejskiej za 20\% emisji szkodliwych substancji do atmosfery odpowiedzialny jest transport drogowy, pozostając pod względem emisji gazów cieplarnianych drugim co do wielkości sektorem gospodarki. W celu ograniczania emisji tych gazów UE zaleca sukcesywny wzrost udziału energii ze źródeł odnawialnych w paliwach używanych w transporcie. Do silników ZI najpowszechniej stosowane jest biopaliwo etanolowe E85. Etanol to atrakcyjny i perspektywiczny komponent do produkcji paliw do tych silników. Do jego niekwestionowalnych zalet można zaliczyć między innymi zmniejszenie emisji szkodliwych substancji do powietrza atmosferycznego, mniejsze oddziaływanie toksyczne, jak również możliwość zwiększenia poziomu bezpieczeństwa energetycznego. Równocześnie jego odmienne od benzyny właściwości fizykochemiczne wymagają dalszych badań i rozwiązania wielu problemów w celu opracowania optymalnych mieszanin paliw etanolowo-benzynowych o wymaganych właściwościach użytkowo-eksploatacyjnych, kompatybilnych z obecnymi konstrukcjami silników ZI.
\end{abstract}

Słowa klucze: paliwa alternatywne, paliwo etanolowe, Flex Fuel Vehicles.

\section{Ethanol fuels for spark ignition engines}

In the European Union, road transport is responsible for $20 \%$ of emissions into the atmosphere, while remaining in terms of greenhouse gas emissions, the second largest sector of the economy. In order to reduce the emissions of these gases, the EU recommends the gradual increase in the share of renewable energy in fuels used for transport. In the case of fuels used for SI engines, the most widely used biofuel is E85 ethanol fuel. Ethanol is an attractive and perspective component for the production of fuels for spark ignition engines. Its undisputed advantages may include, amongst other things, the potential of the reduction of harmful emissions into the atmosphere, less toxic effects, as well as the possibility of increasing the level of energy security. Simultaneously its different physical and chemical properties with regard to gasoline, require further research and solution to lots of technical challenges for the development of optimal ethanol-gasoline fuel blends, having the required operational properties, as well as being compatible with existing and future engine constructions.

Key words: alternative fuels, fuel ethanol, Flex Fuel Vehicle (FFV).

\section{Wstęp}

Od wielu lat podejmowane są na całym świecie coraz bardziej intensywne działania zmierzające do ochrony środowiska naturalnego człowieka. W Unii Europejskiej (UE) drugim co do wielkości sektorem gospodarki odpowiedzialnym za 20\% emisji szkodliwych substancji, w tym gazów cieplarnianych (GHG - greenhouse gases), do atmosfery jest transport drogowy. W celu ograniczania emisji tych gazów UE zaproponowała, aby w krajach członkowskich do roku 2020 zmniejszono udział ditlenku węgla w powietrzu atmosferycznym o co najmniej $20 \%$ w porównaniu ze stanem z 1990 roku [7].

Dyrektywa 2009/28/WE Europejskiego Parlamentu i Rady z dnia 23 kwietnia 2009 roku, w sprawie promocji i stosowania biopaliw lub innych paliw ze źródeł odnawialnych do celów transportowych, określa kierunki zmniejszenia emisji GHG. Zaleca ona sukcesywny wzrost udziału energii ze źródeł odnawialnych w paliwach stosowanych w transporcie, tj. w benzynie silnikowej i w oleju napędowym. Z kolei 
dyrektywa 2009/30/WE Parlamentu Europejskiego i Rady z dnia 23 kwietnia 2009 roku, w sprawie jakości paliw oraz wprowadzająca mechanizm monitorowania i ograniczania emisji gazów cieplarnianych, proponuje między innymi wzrost udziału bioetanolu w benzynie silnikowej [3, 4]. Biorąc także pod uwagę konieczność dywersyfikacji paliw ze względu na zmniejszające się zasoby ropy naftowej, paliwa alternatywne nabierają coraz większego znaczenia.

Zasadniczym kryterium decydującym o możliwości stosowania paliwa jako alternatywnego do obecnie używanych pojazdów są jego właściwości proekologiczne $[5,8,10,11]$. Równocześnie paliwo jest istotnym elementem procesu inżynierii samochodowej, na który składa się też wybór materiałów konstrukcyjnych, takich jak: metale, tworzywa sztuczne i oleje smarowe. Właściwości paliwa determinują limity dla regulacji silnika i optymalizacji emisji szkodliwych składników spalin, osiągów oraz właściwości użytkowo-eksploatacyjnych. Paliwo powinno zatem zapewniać techniczną funkcjonalność i odpowiednie właściwości użytkowo-eksploatacyjne pojazdu, spełnianie właściwych norm emisji w cyklu życia silnika oraz utrzymanie gwarancji producenta pojazdu.

Wprowadzone w roku 2009 dyrektywy europejskie RED i FQD umożliwiają zwiększenie zawartości etanolu w tradycyjnej benzynie silnikowej do 10\% (V/V), a także sprzyjają budowie samochodów typu Flex Fuel Vehicle (FFV), przystosowanych do zasilania paliwem zawierającym do $85 \%(V / V)$ etanolu. W celu umożliwienia rozwoju rynku pojazdów FFV w Unii Europejskiej i zapewnienia ich podstawowej funkcjonalności Europejski Komitet Normalizacyjny CEN opracował dokument normalizacyjny CWA 15293:2005 [18], w którym ustalono niezbędne minimum jakościowe dla paliwa etanolowego E85, aby mogło ono być wprowadzone na rynek. Wkrótce jednak pojazdy FFV zostały poddane zaostrzonym wymaganiom normy emisji spalin Euro 5, która zaczęła obowiązywać od września 2009 roku [20]. W związku z tym wytyczne zawarte w CWA okazały się niewystarczające do sprostania wymaganiom europejskich norm emisyjnych. Dlatego też kolejnym krokiem było opracowanie specyfikacji technicznej CEN/TS 15293:2011 [17], którą opublikowano w lutym 2011 roku. W chwili obecnej natomiast trwają prace w CEN nad zmianą statusu tej specyfikacji i zastąpienia jej normą europejską. Specyfikacja [17] zmieniła limity niektórych cech jakościowych i wprowadziła limity dodatkowych parametrów w porównaniu z pierwotnymi wymaganiami [18].
Wybór cech jakościowych paliwa E85 [16] został oparty na badaniach i doświadczeniach rynku.

Właściwości fizykochemiczne i użytkowe paliw mających w swym składzie znaczny udział etanolu są w dużym stopniu odmienne od tych, jakimi charakteryzują się tradycyjne benzyny, które mogą zawierać, zgodnie z normą PN-EN 228:2013, do 10\% (V/V) etanolu [10]. Przedmiotowe różnice narastają wraz ze zwiększającym się udziałem etanolu w benzynie, co w rezultacie wymusza wprowadzenie wielu istotnych zmian materiałowych, konstrukcyjnych i regulacyjnych w silniku o zapłonie iskrowym (ZI), w celu dostosowania go do bezpiecznej i niezawodnej eksploatacji na takich paliwach, a równocześnie zoptymalizowania jego parametrów technicznych i użytkowych. W tablicy $1[10,11]$ zawarto najważniejsze, z punktu widzenia właściwości fizykochemicznych oraz użytkowo-eksploatacyjnych, różnice pomiędzy benzyną silnikową a etanolem.
Tablica 1. Najważniejsze różnice pomiędzy benzyną silnikową a etanolem

\begin{tabular}{|l|c|c|}
\hline \multicolumn{1}{|c|}{ Właściwość } & $\begin{array}{c}\text { Benzyna zgodna } \\
\text { z PN-EN228 }\end{array}$ & Etanol \\
\hline Formuła chemiczna & $\mathrm{mC}_{\mathrm{n}} \mathrm{H}_{2 \mathrm{n}}$ & $\mathrm{C}_{2} \mathrm{H}_{5}$-OH \\
\hline Masa cząsteczkowa & 114,2 & 46 \\
\hline Gęstość $\left[\mathrm{kg} / \mathrm{m}^{3}\right]$ & $720 \div 775$ & 794 \\
\hline Wartość opałowa $[\mathrm{MJ} / \mathrm{kg}]$ & $42,3 \div 43,5$ & 26,8 \\
\hline Temperatura wrzenia $\left[{ }^{\circ} \mathrm{C}\right]$ & $20 \div 220$ & 77,8 \\
\hline Liczba oktanowa badawcza LOB & 95 min & $120 \div 135$ \\
\hline Liczba oktanowa motorowa LOM & 85 min & $100 \div 106$ \\
\hline Temperatura zapłonu [ $\left.{ }^{\circ} \mathrm{C}\right]$ & -42 & 12,8 \\
\hline Temperatura samozapłonu [ $\left.{ }^{\circ} \mathrm{C}\right]$ & $300 \div 450$ & 420 \\
\hline Ciepło odparowania $[\mathrm{kJ} / \mathrm{kg}]$ & 350 & $855 \div 870$ \\
\hline $\begin{array}{l}\text { Stechiometryczny współczynnik nadmiaru } \\
\text { powietrza spalanej mieszanki } \lambda\end{array}$ & 14,7 & 9,0 \\
\hline $\begin{array}{l}\text { Zakresy granicznych współczynników } \\
\text { nadmiaru powietrza } \lambda \text { spalanej mieszanki }\end{array}$ & 6,0 do 22,0 & 3,5 do 17,0 \\
\hline
\end{tabular}

W konsekwencji właściwości fizykochemiczne i użytkowe paliw zawierających w swym składzie znaczny udział etanolu są w dużym stopniu odmienne od tych, jakimi charakteryzują się tradycyjne benzyny, zgodne z PN-EN 228:2013. Przedmiotowe różnice narastają wraz ze zwiększającym się udziałem etanolu w benzynie, a najistotniejsze $\mathrm{z}$ nich to $[9,10]$ :

- emisja ditlenku węgla $\left(\mathrm{CO}_{2}\right)$ podczas stosowania etanolu jako paliwa w samochodach jest równoważona przez $\mathrm{CO}_{2}$ wychwytywane w czasie upraw. W rezultacie samochody FFV, spalając paliwa wysokoetanolowe, emitują mniej $\mathrm{CO}_{2}$ netto niż konwencjonalne pojazdy na jednostkę przebytej drogi [5];

- zmniejszająca się wartość opałowa biopaliwa wraz ze wzrostem udziału etanolu; 
- szybko zwiększające się ciepło odparowania biopaliwa w miarę podwyższania zawartości etanolu. Etanol charakteryzuje się ciepłem parowania $855 \mathrm{~kJ} / \mathrm{kg}$, o $280 \%$ większym niż benzyna. Powoduje to o około $250 \%$ lepsze chłodzenie ładunku mieszanki paliwowo-powietrznej, obniżenie emisji $\mathrm{NO}_{\mathrm{X}}$, gdy stosowane jest paliwo E85, co umożliwia zwiększenie wartości stopnia sprężania i kąta wyprzedzenia zapłonu;

- nieaddytywny przyrost prężności par biopaliwa ze wzrostem zawartości etanolu. Większa prężność par paliwa i zmniejszona temperatura końca jego parowania sprzyja powstawaniu kor-

Tablica 2. Najważniejsze różnice pomiędzy benzyną silnikową a biopaliwem E85

\begin{tabular}{|l|c|c|}
\hline \multicolumn{1}{|c|}{ Właściwość } & $\begin{array}{c}\text { Benzyna zgodna } \\
\text { z PN-EN 228 }\end{array}$ & Biopaliwo E85 \\
\hline Gęstość $\left[\mathrm{kg} / \mathrm{m}^{3}\right]$ & $720 \div 775$ & $\sim 785$ \\
\hline Wartość opałowa [MJ/kg] & $42,3 \div 43,5$ & $\sim 29$ \\
\hline Liczba oktanowa badawcza LOB & $95 \mathrm{~min}$ & $>105$ \\
\hline Liczba oktanowa motorowa LOM & $85 \mathrm{~min}$ & $>90$ \\
\hline $\begin{array}{l}\text { Współczynnik nadmiaru powietrza mieszanki } \\
\text { paliwowo-powietrznej }\end{array}$ & $14,5 \div 14,7$ & $\sim 9,7$ \\
\hline Ciepło odparowania [kJ/kg] & 350 & 780 \\
\hline
\end{tabular}
ków parowych w układzie zasilania, a tym samym nieciągłości w pracy silnika mogących mieć poważne konsekwencje dla bezpieczeństwa jazdy;

- zwiększenie liczb oktanowych - badawczej i motorowej (LOB i LOM) biopaliw w miarę podwyższania udziału etanolu;

- obniżanie temperatury płomienia podczas procesów spalania mieszanek zawierających coraz większy udział etanolu;

- pogarszanie właściwości smarnych biopaliw, co wynika z wytwarzania coraz mniejszej ilości sadzy podczas spalania paliw o wzrastającym udziale etanolu. Ma to ujemny wpływ między innymi na zużycie gniazd zaworowych i współpracujących z nimi zaworów;

- duża higroskopijność etanolu, a zatem łatwość pochłaniania wody - prowadzi do zatykania filtrów i zalewania odstojników. Ponadto po osiągnięciu udziału około 5\% $(V / V)$ wody w paliwie następuje jego rozwarstwienie, a woda wraz z etanolem jako oddzielna faza osiada na dnie zbiornika paliwa, powodując zaburzenia procesów spalania lub unieruchomienie silnika. Dochodzić też może do zamarzania wody w paliwie i związanych z tym następstw. Ponadto łatwość pochłaniania wody przez etanol przyczynia się do intensyfikacji procesów korozyjnych elementów silnika;

- alkohol jako rozpuszczalnik może wymywać osady z elementów oraz części składowych układu paliwowego i przenosić je do filtrów i podzespołów układów wtrysku paliwa;

- często benzyny zawierające biokomponenty (w tym etanol) cechuje niekompatybilność z niektórymi materiałami konstrukcyjnymi (uszczelnienia, elementy układów paliwowych, tj.: zbiorniki paliwa, przewody paliwowe, elementy wtryskiwaczy i pomp paliwa itp.).

W przypadku biopaliw zawierających do $85 \%(V / V)$ etanolu różnice pomiędzy właściwościami fizykochemicznymi i użytkowymi są tak duże w porównaniu z tradycyjnymi benzynami silnikowymi, że wymuszają wprowadzenie wielu zmian konstrukcyjno-materiałowych i regulacyjnych w silniku, w celu dostosowania go do eksploatacji na takich paliwach - tablica $2[10,11]$. 
Obecnie benzyna silnikowa E85 jest najbardziej rozpowszechniona w krajach, które w dużym stopniu realizują programy zastępowania paliw konwencjonalnych paliwami uzyskiwanymi z odnawialnych źródeł energii. Wiele instalacji do produkcji etanolu powstało także w Hiszpanii, Niemczech, Holandii i Wielkiej Brytanii.

\section{Zalety i wady stosowania etanolu jako paliwa alternatywnego}

Etanol jest wysokooktanowym, organicznym związkiem tlenowym, który ze względu na swoje walory użytkowe znalazł zastosowanie jako komponent benzyny silnikowej.

Charakterystyka spalania, temperatura samozapłonu i zapłonu alkoholu etylowego są wyższe od tych, którymi cechuje się konwencjonalna benzyna silnikowa, co czyni go bezpieczniejszym w czasie transportu i magazynowania.

Przeprowadzone badania dowiodły, że dodanie etanolu do konwencjonalnej benzyny silnikowej wpływa na zwiększenie liczby oktanowej o około 5\% (dla każdych $10 \%$ wprowadzonego dodatkowo alkoholu), lecz jednocześnie przyczynia się do zmniejszenia wartości opałowej paliwa [9].

Równocześnie etanol, ze względu na swoją budowę chemiczną, ma właściwości, które stwarzają problemy eksploatacyjne, między innymi jest całkowicie mieszalny z wodą i węglowodorami w każdej proporcji, a dodatkowo charakteryzuje się higroskopijnością, co wiąże się z tym, że pochłania wilgoć z powietrza.

Bioetanol zaliczany jest do polarnych rozpuszczalników organicznych ze względu na obecność grupy wodorotlenowej. Pomiędzy atomem wodoru w grupie wodorotlenowej jednej cząsteczki a atomem tlenu $\mathrm{w}$ grupie wodorotlenowej drugiej cząsteczki tworzą się wiązania wodorowe, dzięki którym w wyniku asocjacji cząsteczek alkoholi powstają agregaty o masach znacznie przekraczających masę molekularną pojedynczych cząsteczek alkoholi. Wiązania wodorowe pomiędzy cząsteczkami alkoholi są znacznie silniejsze niż wzajemne oddziaływania cząsteczek węglowodorów, gdzie ich przyciąganie się następuje głównie wskutek wpływu słabszych sił Van der Waalsa. Konsekwencją istnienia wiązań wodorowych jest między innymi duża wartość temperatury wrzenia alkoholi (w porównaniu z ich odpowiednikami węglowodorowymi), gdyż rozerwanie wiązań wodorowych wymaga dostarczenia dodatkowej energii.

Obecność alkoholi w benzynie silnikowej stwarza wspomniane już niebezpieczeństwo pochłaniania wody, do której powinowactwo alkoholi jest znane. Im paliwo silnikowe będzie zawierać więcej alkoholu, tym większe ilości wody będzie mogło wchłonąć, co w konsekwencji prowadzi do problemów związanych z korozją praktycznie wszystkich elementów silnika, które są wykonane z żeliwa, stali, miedzi, mosiądzu i aluminium. W celu zminimalizowania procesów korozyjnych należy unikać wykonywania elementów silnika i systemów jego zasilania z wyżej wymienionych materiałów lub stosować odpowiednie pokrycia zabezpieczające [9].

Benzyna silnikowa zawierająca do $10 \%(V / V)$ etanolu jest stosowana do zasilania standardowych silników samochodowych, jednak pod warunkiem dotrzymania przez takie paliwo parametru prężności par, zwłaszcza w okresie letnim (około $60 \mathrm{kPa}$ ). Podczas rozdziału faz benzyna zawierająca poniżej $20 \%(V / V)$ etanolu oraz mająca charakter aromatyczny jest bardziej stabilna. Obecność dwóch faz dyskwalifikuje paliwo i produkt taki nie nadaje się do zasilania silników samochodowych. W celu obniżenia temperatury rozdziału faz do mieszaniny benzynowo-etanolowej dodawane są wyższe alkohole alifatyczne, takie jak: trzeciorzędowy alkohol butylowy, alkohol benzylowy, cykloheksanol oraz toluen. Podstawowym wymogiem podczas produkcji, magazynowania i dystrybucji paliw silnikowych zawierających etanol staje się niedopuszczenie do ich kontaktu z wodą [15], co stwarza określone problemy logistyczne.

Ciepło parowania etanolu ma dużą wartość, zazwyczaj o około $280 \%$ większą niż konwencjonalna benzyna silnikowa, co przyczynia się do chłodzenia strumienia powietrza, w którym paliwo odparowuje. W efekcie tego zjawiska następuje znaczne obniżenie temperatury strumienia w przewodzie i kolektorze dolotowym, a w szczególności w komorze spalania silnika, co prowadzi do większej sprawności napełniania komór spalania silnika. Równocześnie utrudnia to odparowanie cięższych frakcji benzynowych, osiadających na ściankach komory spalania silnika. Możliwe jest zwiększenie stopnia sprężenia i kąta wyprzedzenia zapłonu. Wartość opałowa alkoholu jest mniejsza niż benzyny silnikowej, dlatego potrzebne jest od 1,5 do 1,8 razy więcej alkoholu, aby osiągnąć ilość energii porównywalną z uzyskiwaną przy spalaniu benzyny. Ponadto stechiometryczny stosunek powietrza do paliwa dla alkoholu stanowi około $2 / 3$ do $1 / 2$ tego, co dla benzyny silnikowej. Dlatego też wymagana jest mniejsza ilość powietrza dla całkowitego spalenia takiej ilości alkoholu jak benzyny [9].

Etanol, jako komponent, charakteryzuje się bardzo małą wartością prężności par, a w mieszaninie $\mathrm{z}$ benzyną silnikową powoduje nieaddytywny przyrost tego parametru. W przypadku paliwa E85, ze względu na duży udział etanolu, prężność par finalnego produktu zmniejsza się wraz ze wzrostem jego udziału. W takiej sytuacji problemem technologicznym może być uzyskanie minimalnej, wymaganej specyfikacją, 
prężności par. Jest to sytuacja odwrotna do tej, która występuje dla paliw z małym udziałem etanolu, gdzie problemem jest przekroczenie górnej granicy prężności par dla benzyn silnikowych.

Należy zwrócić uwagę na to, że w zależności od prężności par benzyny bazowej i jej składu chemicznego efekt zmniejszania prężności par po dodaniu etanolu może być tak znaczący, że finalne paliwo nie spełnia wymagań jakościowych. Nie jest zatem oczywiste, że po zmieszaniu dwóch komponentów (etanolu paliwowego i benzyny silnikowej), zgodnych z wymaganiami swoich specyfikacji, otrzymamy produkt, który te wytyczne również spełni. Wielkość efektu obniżenia prężności par dla paliw E85 zależy także od innych czynników, do których można zaliczyć zawartość związków nienasyconych w paliwie.

Istotne jest, aby pamiętać, że zastosowanie benzyn zawierających alkohole do silników starszych generacji może powodować wiele niekorzystnych zjawisk, tj.: puchnięcie i zmiękczanie niektórych naturalnych i syntetycznych gum oraz niektórych tworzyw sztucznych mających kontakt z benzyną zawierającą etanol lub produktami jej spalania (rysunek 1). Przyczynić się to może do uszkodzenia przewodów paliwowych. Dlatego też do silników, które są napędzane paliwami etanolowymi, zaleca się używanie uszczelnień wykonanych z elastomerów fluorowęglowych.

Niekiedy, zwłaszcza w niskiej temperaturze, paliwo z wysoką zawartością etanolu uniemożliwia prawidłowe funkcjonowanie silników pojazdów typu FFV. Zjawisko to spowodowane jest różnicą w lotności pomiędzy etanolem i benzyną silnikową, będącą mieszaniną węglowodorów zawierających od 4 do 12 atomów węgla, charakteryzującą się określonym zakresem wrzenia oraz temperaturą zapłonu. Alkohol etylowy jest natomiast odrębnym pod względem chemicznym związkiem o określonych właściwościach, w niskiej temperaturze nieosiągającym wymaganej lotności w celu podtrzymania procesu spalania. Dlatego zwykle wkomponowuje się więcej benzyny silnikowej (do 30\%) do mieszaniny etanol-benzyna, aby zapewnić skuteczny rozruch silnika [13].
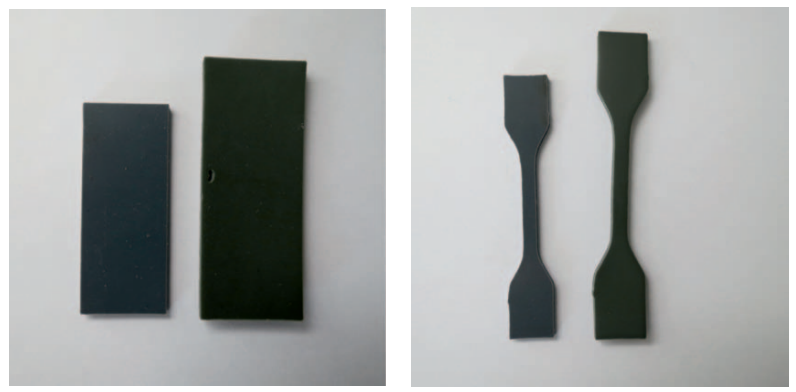

Elastomer silikonowy MVQ
Podobnie jak konwencjonalna benzyna silnikowa, paliwa etanolowe wykazują skłonność do tworzenia osadów na zaworach dolotowych, w komorach spalania oraz na wewnętrznych i zewnętrznych powierzchniach wtryskiwaczy paliwa - rysunki 2 i 3.

Jedną z możliwych przyczyn ich powstawania jest brak pełnej kompatybilności konwencjonalnych dodatków detergentowych wprowadzanych wraz z częścią benzyny silnikowej do paliwa wysokoetanolowego. Najczęściej tego typu dodatki są oparte na poliizobutylenie (PIB) lub aminie polieterowej (PEA). PIB łatwo rozpuszcza się w węglowodorach, natomiast $w$ alkoholu nie, co może być jedną z przyczyn zwiększonej ilości osadów tworzonych na elementach silnika. Wówczas bowiem takie dodatki kumulują się w powstających osadach, intensyfikując ich przyrost, co powoduje tzw. hump effect, czyli efekt garbu, a więc zwiększenia ilości tworzonych osadów w porównaniu z paliwem nieuszlachetnionym [8].

W celu ograniczenia tych niekorzystnych zjawisk należy stosować dopasowane do właściwości paliw etanolowych dodatki detergentowo-dyspergujące na odpowiednim poziomie dozowania.

Inny problem związany jest $\mathrm{z}$ siarczanami powstającymi w trakcie procesu fermentacji etanolu. Mogą one również pochodzić z pewnych typów inhibitorów korozji stosowanych w paliwach E85. Siarczany są rozpuszczalne w etanolu, lecz mogą wytrącać się podczas mieszania etanolu z benzyną silnikową, powodując zatykanie filtra paliwa i wtryskiwaczy paliwa, a także sprzyjać tworzeniu osadów na zaworach dolotowych i w komorach spalania. Duża ilość i lepka konsystencja osadów na zaworach dolotowych, a zwłaszcza na ich trzonkach, może powodować nawet zawieszanie się zaworów i wynikające stąd konsekwencje (rysunek 2a).

Powstawanie opisanych osadów prowadzi do pogorszenia osiągów silników, wzrostu zużycia paliwa oraz emisji szkodliwych składników spalin, korozji układu paliwowego i elementów silnika, zatykania filtrów paliwowych, utrudnionego rozruchu silnika i ogólnie pogorszenia właściwości użytkowo-eksploatacyjnych.

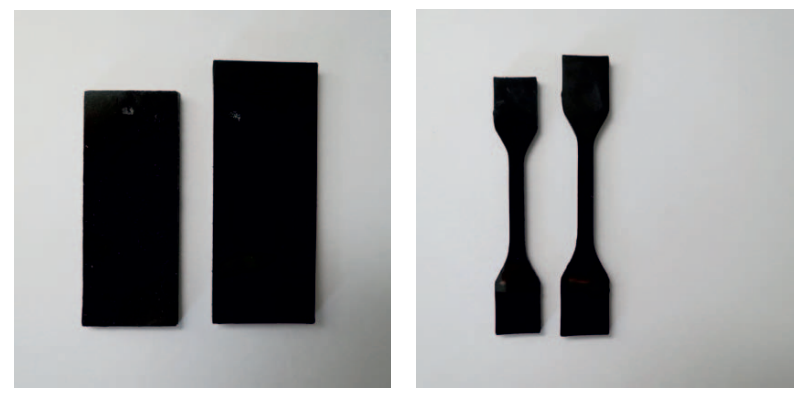

Elastomer nitrylowy NBR 28

Rys. 1. Wpływ paliwa wysokoetanolowego na elastomery (fot. INiG - PIB) 
a)

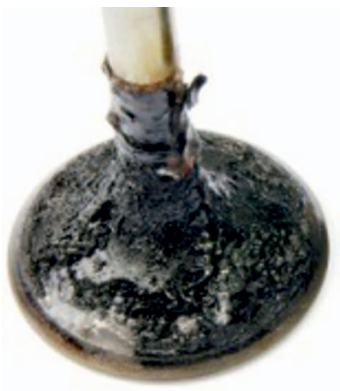

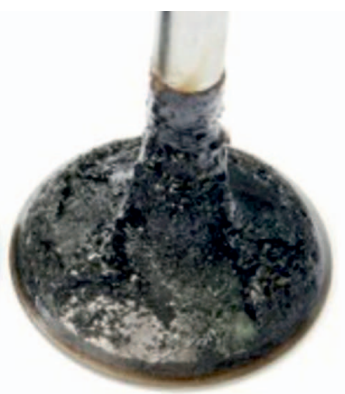

b)

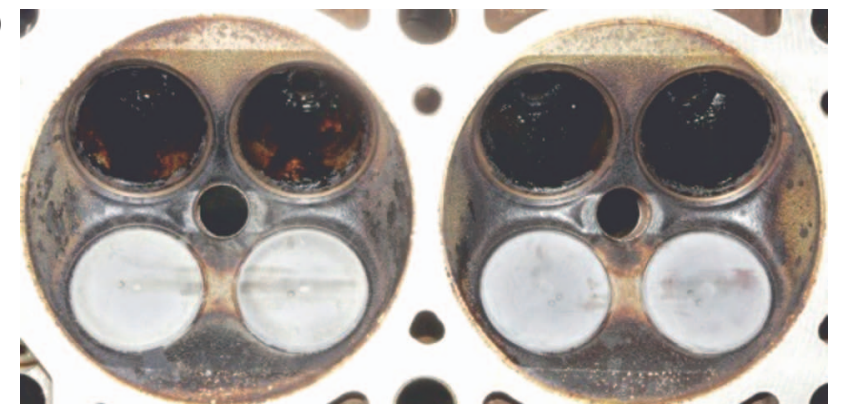

Rys. 2. Osady na zaworach dolotowych (a) i w komorach spalania (b) silnika eksploatowanego na paliwach zawierających etanol (fot. INiG - PIB)
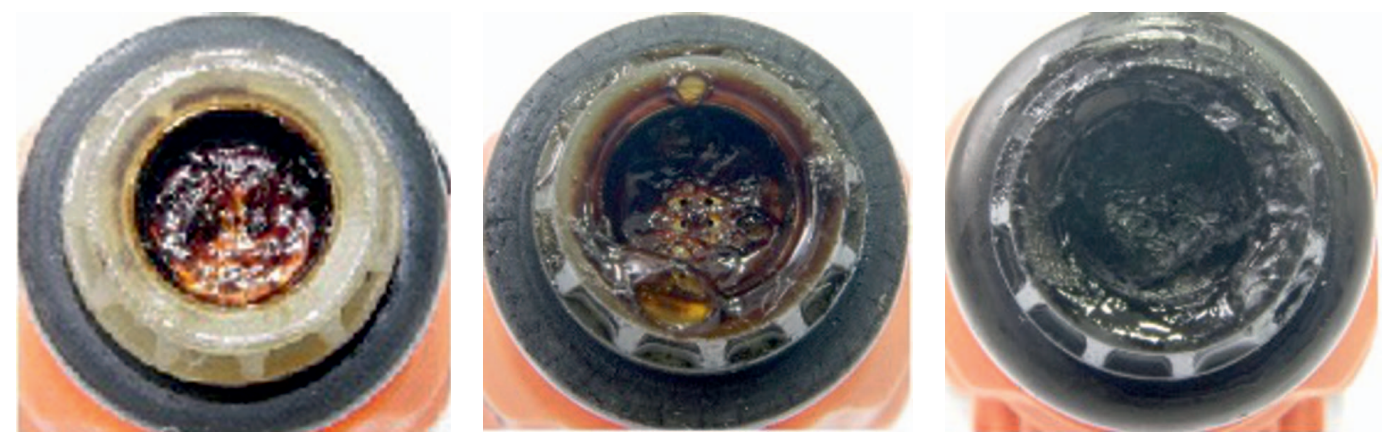

Rys. 3. Osady na końcówce wtryskiwacza silnika FFV eksploatowanego na paliwach E85 (fot. INiG - PIB)

\section{Wpływ paliw etanolowych na emisję szkodliwych substancji do atmosfery}

Szkodliwe zanieczyszczenia powietrza, powstałe na skutek spalania paliwa w silniku samochodowym, są emitowane z układu wydechowego pomimo ich przejścia przez katalityczny układ oczyszczania spalin. Ograniczanie emisji szkodliwych substancji do powietrza atmosferycznego obejmuje $\mathrm{NO}_{x}, \mathrm{CO}, \mathrm{HC}$, PM i inne związki toksyczne powstające w powietrzu, których przyczyną są spaliny, np. formaldehyd,1,3-butadien i inne, a także $\mathrm{CO}_{2}$.

Harmonogram stopniowego ograniczania szkodliwych składników spalin w zakresie $\mathrm{NO}_{\mathrm{x}}, \mathrm{CO}, \mathrm{HC}, \mathrm{PM}$ określają normy emisji Euro. $\mathrm{Z}$ kolei harmonogram ograniczania $\mathrm{CO}_{2}$ podano w rozporządzeniu Parlamentu Europejskiego i Rady (WE) nr 443/2009 z dnia 23 kwietnia 2009 roku określającym normy emisji dla nowych samochodów osobowych w ramach zintegrowanego podejścia Wspólnoty Europejskiej na rzecz zmniejszenia emisji $\mathrm{CO}_{2}$ z lekkich pojazdów samochodowych [19]. Według zapisów rozporządzenia [19], stosowanie niektórych alternatywnych paliw może zapewnić znaczącą redukcję emisji $\mathrm{CO}_{2}$ na wszystkich etapach łańcucha paliwowego. Artykuł 6 dokumentu mówi o docelowych indywidualnych poziomach emisji $\mathrm{CO}_{2}$ dla pojazdów zasilanych paliwem alternatywnym. Zapis umieszczony w tym artykule promuje wykorzystanie do napędu silników ZI paliwa etanolowego E85. Z tego względu proponuje się, aby indywidualny poziom emisji $\mathrm{CO}_{2}$ dla każdego takiego samochodu, który może być przystosowany do zasilania paliwem etano- lowym E85 spełniającym wymagania odpowiednich przepisów wspólnotowych, a także europejskiej specyfikacji, został zmniejszony o 5\% do dnia 31 grudnia 2015 roku. Jednak redukcję tę można zastosować tylko wtedy, gdy w danym państwie członkowskim, w którym pojazd został zarejestrowany, co najmniej 30\% stacji paliw udostępni paliwo etanolowe i spełni ono kryteria zrównoważonego rozwoju, wyznaczone dla biopaliw dyrektywami RED i FQD.

Paliwo etanolowe jest paliwem silnikowym, które również powoduje emisję toksycznych substancji chemicznych oraz gazów cieplarnianych podczas dystrybucji i magazynowania oraz spalania w silniku. Emisja zanieczyszczeń do powietrza atmosferycznego ma miejsce w wyniku odparowania paliwa i jego spalania w silnikach samochodowych. Jednak na ogół jest ona mniejsza w porównaniu z emisją podczas stosowania konwencjonalnej benzyny silnikowej.

Zanieczyszczenie powietrza związkami chemicznymi na skutek parowania paliwa etanolowego lub benzyny silnikowej może występować $\mathrm{w}$ wyniku wydostawania się par z odpowietrzników zbiorników paliwa lub wycieków paliwa. Przenikanie par następuje przez materiały konstrukcyjne układu paliwowego wykonane z tworzyw sztucznych. Ten rodzaj emisji występuje częściej w przypadku benzyny silnikowej o niskiej zawartości etanolu, jak np. E5 czy E10. Odpowietrzenie zbiornika paliwa ma również miejsce, gdy pary paliwa wydostają się ze zbiornika podczas tankowania pojazdu 
oraz podczas odparowywania benzyny silnikowej w wyniku podwyższenia temperatury otoczenia. Ten rodzaj emisji jest mniej powszechny w samochodach typu FFV. Ma to związek z ciągłym doskonaleniem materiałów uszczelniających oraz systemów odpowietrzania, które są stosowane w tego typu samochodach [8].

Badania prowadzone przez różne ośrodki w zakresie wpływu spalania paliw etanolowych na zanieczyszczenie powietrza atmosferycznego na flotach różnych modeli samochodów nie zawsze podają zbieżne i jednoznaczne wyniki. Jest to spowodowane dużą liczbą zmiennych, różnymi procedurami prowadzenia badań oraz odmiennymi konstrukcjami silników i układów oczyszczania spalin badanych pojazdów.

Samochody FFV, przystosowane do spalania paliwa etanolowego E85, są obecnie powszechnie dostępne w USA i Brazylii. W Unii Europejskiej rynek tych samochodów jest na etapie przyspieszonego rozwoju. W Europie największa liczba pojazdów typu FFV występuje obecnie w Szwecji (około 60 000), a następnie w Niemczech, Holandii i Francji [1]. Dotychczas w USA wykonano najszersze badania w zakresie pomiarów wpływu paliw etanolowych na wielkość emisji różnych regulowanych i nieregulowanych składników szkodliwych spalin samochodów typu FFV. Na przykład National Renewable Energy Laboratory (NREL) w USA przeprowadziło badania w zakresie szczegółowej analizy danych z badań, odnosząc je do obowiązujących wymagań emisji [1]. Studia te obejmowały porównanie zmian w emisji z pojazdów FFV zasilanych paliwem etanolowym E85 z emisją z pojazdów FFV zasilanych konwencjonalną benzyną silnikową i pojazdów samochodowych zasilanych konwencjonalną benzyną silnikową, nieprzystosowanych do paliwa etanolowego E85. Wszystkie pojazdy spełniały standardy U.S. Environmental Protection Agency (EPA) Tier 1. Wyniki tej analizy [14] pokazały, że średnia emisja ditlenku węgla $\mathrm{CO}_{2}$ ze spalania badanych paliw we wszystkich typach pojazdów albo uległa zmniejszeniu w przypadku zasilania E85, albo statystycznie nie stwierdzono istotnej różnicy pomiędzy spalaniem paliwa etanolowego E85 i benzyny silnikowej. Znaczące różnice zauważono w przypadku emisji innych toksycznych związków chemicznych powstających na skutek spalania paliw w silniku, nie tylko w zależności od zastosowanego paliwa, ale także konstrukcji sil- ników opisywanej spełnianymi przez nie standardami emisji spalin EPA Tier 1 lub Tier 2 [14]. Mianowicie porównania pojazdów typu FFV realizujących wymagania EPA Tier 1 i zasilanych paliwem E85 z pojazdami konwencjonalnymi spełniającymi te same wymagania (EPA Tier 1) i zasilanymi standardową benzyną silnikową wykazały zmniejszenie średnio o $54 \%$ emisji $\mathrm{NO}_{\mathrm{x}}$, o $27 \%$ emisji węglowodorów pochodzenia niemetanowego (NMHC) i o 18\% emisji $\mathrm{CO}$ w przypadku pojazdów typu FFV, zasilanych paliwem E85 [14]. Podobne badania przeprowadzone dla samochodów spełniających standardy emisji EPA Tier 2 wykazały zmniejszenie średnio o $28 \%$ emisji $\mathrm{NO}_{\mathrm{x}}$ i o $20 \%$ emisji $\mathrm{CO}$ w przypadku pojazdów typu FFV, natomiast nie zaobserwowano istotnych różnic w zakresie emisji NMHC pomiędzy pojazdami FFV zasilanymi paliwem E85 i pojazdami konwencjonalnymi zasilanymi standardową benzyną [14].

Jednocześnie pojazdy typu FFV napędzane paliwem etanolowym powodują kilkukrotny wzrost emisji etanolu, formaldehydu, aldehydu octowego i metanu do otaczającego powietrza, w stosunku do pojazdów zasilanych benzyną silnikową zgodną z wymaganiami PN-EN 228. Jednak, pomimo wzrostu emisji aldehydu w przypadku stosowania mieszanki etanolu z benzyną silnikową, zagrożenie dla środowiska przez te substancje jest znacznie mniejsze, niż przez rakotwórcze wielopierścieniowe związki aromatyczne, tworzące się podczas spalania konwencjonalnej benzyny silnikowej. Dlatego większa procentowa zawartość alkoholu w mieszance paliwowej przyczynia się do mniejszego zagrożenia środowiska naturalnego, niż ma to miejsce przy stosowaniu standardowej benzyny silnikowej [15]. Zatem w przypadku paliw etanolowych ograniczenie emisji szkodliwych substancji do powietrza atmosferycznego dotyczy takich substancji jak: tlenki węgla $\left(\mathrm{CO}_{2} \mathrm{i} \mathrm{CO}\right)$ oraz tlenki azotu $\left(\mathrm{NO}_{\mathrm{x}}\right)$ i w mniejszym stopniu węglowodorów pochodzenia niemetanowego (NMHC), a także związków toksycznych, takich jak 1,3-butadien i inne. Równocześnie jednak obserwuje się wzrost emisji aldehydu octowego, formaldehydu i metanu. Na szczególne podkreślenie zasługuje fakt, że stosowanie mieszanek etanol-benzyna silnikowa umożliwia ograniczenie zanieczyszczenia powietrza atmosferycznego, w zakresie emisji GHG. Jednocześnie może spowalniać wyczerpywanie się złóż paliw ropopochodnych, dzięki ich zastępowaniu przez surowce odnawialne.

\section{Oddziaływanie paliwa etanolowego na smarowy olej silnikowy}

Jednym z problemów, które wynikają z eksploatacji paliw etanolowych, jest przedostawanie się etanolu oraz towarzyszącej mu wody do smarowego oleju silnikowego. W wyniku tego tworzą się substancje o charakterze kwaśnym. Zjawisko to nie wymaga wysokiej temperatury, w przeciwieństwie do tworzenia się kwasów w procesach utleniania i nitratacji. Słabe kwasy organiczne powstają $\mathrm{w}$ oleju smarowym na skutek procesów łączenia się tlenu z węglowodorami (tlen wbudowuje 
się w cząsteczkę). Z kolei mocne kwasy nieorganiczne tworzą się w trakcie spalania paliwa (głównie kwas azotowy, w przypadku paliw o bardzo małej zawartości siarki), zwłaszcza przy stosowaniu w silnikach układu EGR, powodującego częściowy powrót spalin do komór spalania silnika wraz z tlenkami azotu, które w połączeniu z wodą tworzą kwas azotowy. Ponadto niespalony etanol, który dostał się do oleju silnikowego, może reagować z tlenem, tworząc kwas octowy. Obecność kwasu octowego i wody w smarowym oleju silnikowym niesie za sobą wysokie ryzyko korozji silnika. Procesy korozyjne są szczególnie niebezpieczne dla elementów silnika wykonanych z metali miękkich używanych na panewki łożysk ślizgowych, np.: Cu-Sn-P, Cu-Sn-Pb, Al-Sn, powodując korozję $\mathrm{Sn}$ i $\mathrm{Pb}$ oraz tworząc siarczki miedzi $[6,11,12]$. Zakwaszenie oleju smarowego ograniczane jest do czasu zachowania odpowiedniej rezerwy alkalicznej (całkowitej liczby zasadowej) lub do momentu utrzymania zawartości dodatków uszlachetniających (przede wszystkim dyspergujących) na odpowiednim poziomie [2].

Niespalone w silniku paliwo etanolowe może przyczyniać się do powstawania osadów w misce olejowej, których ilość jest zależna od obecności olefin w benzynie silnikowej. Olefiny mają tendencję do polimeryzacji w niskiej temperaturze, zwłaszcza w obecności powstałego kwasu octowego. Skutkuje to powstawaniem żywic. Tworzone w ten sposób osady początkowo są rozproszone w oleju dzięki obecności dyspergatorów. Jednak, ze względu na ich masę cząsteczkową, aglomerują w misce olejowej, intensyfikując powstawanie osadów i szlamów niskotemperaturowych, zwiększając tym samym lepkość smarowego oleju silnikowego. W konsekwencji ich obecność może prowadzić do zatykania kanałów smarowych i ograniczenia przepływu oleju smarowego przez układ smarowania silnika.

Etanol jest substancją, która nie miesza się całkowicie ze środkiem smarowym. Właściwość ta zwiększa ryzyko wzrostu stopnia zużycia silnika, zwłaszcza w przypadku tych jego części, dla których wymagana jest wysoka lepkość dynamiczna HTHS (High Temperature High Shear Rate). Ze względu na charakterystykę rozpuszczalności etanolu, potencjalnie może on usuwać cząsteczki z powierzchni metalu, a tym samym zmniejszać grubość filmu olejowego pomiędzy współpracującymi ciernie powierzchniami. W konsekwencji nie jest zapewnione tworzenie i utrzymywanie granicznej warstwy smarnej, w związku z tym wzrasta zużycie na skutek występowania tarcia granicznego lub półsuchego. Dodatkowo w silnikach z bezpośrednim wtryskiem paliwa może dochodzić do wzrostu stężenia niespalonego etanolu, który będzie oddziaływać na cienką warstwę filmu olejowego na tulejach cylindrowych, powodując jej wymywanie, co zintensyfikuje procesy zużycia ściernego tulei i pierścieni tłokowych.

Rozcieńczenie smarowego oleju silnikowego etanolem może być szczególnie duże w przypadku, gdy silnik jest często uruchamiany (rozgrzewany i chłodzony) w warunkach zimowej eksploatacji na krótkich odcinkach. Odparowanie etanolu z oleju smarowego możliwe jest podczas normalnych warunków eksploatacji, nie powodując przy tym podwyższonego zużycia elementów roboczych silnika.

\section{Podsumowanie}

Od wielu lat podejmowane są na całym świecie coraz bardziej intensywne działania zmierzające do ochrony środowiska naturalnego człowieka. Etanol jest atrakcyjnym, a zatem perspektywicznym komponentem do produkcji paliw do silników ZI. Do jego niekwestionowalnych zalet można zaliczyć między innymi: zmniejszenie emisji szkodliwych substancji do powietrza atmosferycznego, mniejsze oddziaływanie toksyczne, jak również możliwość zwiększenia poziomu bezpieczeństwa energetycznego poprzez dywersyfikację stosowanych paliw. Należy jednak mieć na uwadze, że paliwa skomponowane z jego udziałem charakteryzują się obniżonymi wskaźnikami energetycznymi, gorszymi wskaźnikami stabilności, wymagającymi poprawy właściwościami użytkowo-eksploatacyjnymi, oraz wyższymi kosztami ich produkcji.
Etanol nie jest tradycyjnym paliwem i w dalszym ciągu konieczne są badania umożliwiające rozwiązanie wielu problemów związanych z jego eksploatacją. Przede wszystkim niezbędne jest opracowanie dedykowanego do takich paliw pakietu dodatków uszlachetniających, zapewniającego utrzymanie parametrów paliwa na poziomie gwarantującym odpowiednie właściwości użytkowo-eksploatacyjne.

Ponadto wprowadzenie na rynek nowego rodzaju paliw wymaga, oprócz prac badawczo-normalizacyjnych, rozwiązywania specyficznych problemów organizacyjno-logistycznych. Niezbędne jest między innymi zapewnienie odrębnej floty cystern transportujących paliwo, zbiorników magazynowych u producenta oraz zmiana systemu dystrybucji na stacjach oferujących paliwa etanolowe.

Prosimy cytować jako: Nafta-Gaz 2016, nr 9, s. 761-769, DOI: 10.18668/NG.2016.09.12

Artykuł nadesłano do Redakcji 20.04.2016 r. Zatwierdzono do druku 3.06.2016 r. 


\section{Literatura}

[1] Available FFV Models. Available FFV brands (beginning of 2009); http://www.best-europe.org/Pages/ContentPage. aspx?id $=589$

[2] Bergström K., Melin S. A., Coleman J.: The New ECOTEC Turbo BioPower Engine from GM Powertrain - Utilizing the Power of Nature's resources. 28th Internationales Wiener Motoren symposium 2007.

[3] Danek B.: Wpływ właściwości frakcji benzynowych na parametry sktadu frakcyjnego paliwa etanolowego E85. Nafta-Gaz 2012, nr 10, s. 708-713.

[4] Danek B.: Zmiany właściwości określajacych stabilność chemiczna biopaliwa E85 podczas jego magazynowania. Nafta-Gaz 2011, nr 8, s. 577-580.

[5] Life Cycle Emissions; http://www.afdc.energy.gov/afdc/ vehicles/emissions_e85.html (dostęp: 3.02.2014).

[6] MAHLE Systems with optimized friction properties for greater fuel efficiency and lower $\mathrm{CO}_{2}$ Emission, PERFORMANCE Customer Magazine. Components and Systems for the Engine and its Periphery 2009.

[7] Pałuchowska M.: Określenie wpływu różnej zawartości biokomponentów (bioetanol, EETB, komponent bioetanolowy 80/20) na jakość formut benzynowych. Etap I. Dokumentacja Instytutu Technologii Nafty, Kraków 2007, nr 4056, s. 9-33.

[8] Pałuchowska M., Stępień Z., Żak G: The prospects for the use of etanol as a fuel component and its potential in the reduction of exhaust emissions. Combustion Engines 2014, vol. 158, nr 3, s. 80-92. PTNSS-2014-309.

[9] Schwahn H., Lutz U.: Deposit Formation of Flex Fuel Engines Operated on Ethanol and Gasoline Blends. SAE Paper No. 2010-01-1464.

[10] Stępień Z.: Wielokierunkowe badania wplywu paliw wysokoetanolowych na tworzenie osadów w silnikach z zapłonem iskrowym. Combustion Engines 2015, vol. 54, nr 3, s. 608-618. PTNSS-2015-3418.

[11] Stępień Z.: Zagrożenia eksploatacyjne stwarzane przez paliwa

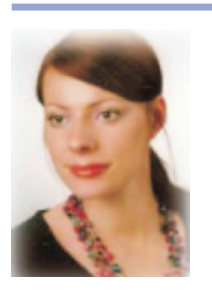

Mgr inż. Magdalena ŻÓŁTY

Specjalista badawczo-techniczny w Zakładzie Oceny Właściwości Eksploatacyjnych; kierownik Laboratorium Badań Właściwości Użytkowych.

Instytut Nafty i Gazu - Państwowy Instytut Badawczy ul. Lubicz 25 A, 31-503 Kraków

E-mail:magdalena.zolty@inig.pl etanolowe dla silników o zapłonie iskrowym. [W:] Paliwa alkoholowe dla transportu - uwarunkowania, badania i rozwój. Prace Naukowe Instytutu Nafty i Gazu - Państwowego Instytutu Badawczego 2015, nr 204, s. 68-94. DOI: 10.18668/ PN2015.204.

[12] Tomanik E.: Some tribological issues on flex-fuel engines. Int. Workshop on Ethanol ICE, S. Paulo 4.10.2012.

[13] Urzędowska W., Stępień Z.: Oddziaływanie paliwa na zmiany właściwości użytkowych oleju smarowego w silniku z ZI typu FlexFuel. Nafta-Gaz 2012, nr 6, s. 377-387.

[14] Yanowitz J., McCormick R. L.: Effect of E85 on Tailpipe Emissions from Light-Duty Vehicles. Journal of the Air \& Waste Management Association, February 2009, vol. 59, s. 172-182.

[15] Yüksel F., Yüksel B.: The use of ethanol-gasoline blend as a fuel in an SI engine. Renewable Energy 2004, vol. 29, s. 1181-1191.

\section{Akty prawne i normatywne}

[16] CEN/TR 15993 Automotive fuels - Ethanol (E85) automotive fuel-Background to the parameters required and their respective limits and determination.

[17] CEN/TS 15293:2011 Automotive fuels - Ethanol (E85) automotive fuel-Requirements and test methods.

[18] CWA 15293:2005 Automotive fuels - Ethanol E85 - Requirements and test methods.

[19] Regulation (EC) No 443/2009 of the European Parliament and of the Council of 23 April 2009 setting emission performance standards for new passenger cars as part of the Community's integrated approach to reduce $\mathrm{CO}_{2}$ emissions from light-duty vehicles. Text with EEA relevance.

[20] Regulation (EC) No 715/2007 of the European Parliament and of the Council of 20 June 2007 on type approval of motor vehicles with respect to emissions from light passenger and commercial vehicles (Euro 5 and Euro 6) and on access to vehicle repair and maintenance information.

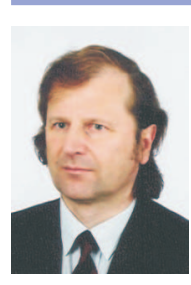

Dr inż. Zbigniew STĘPIEŃ

Adiunkt; kierownik Pracowni Badań Silnikowych i Trybologicznych Zakładu Oceny Właściwości Eksploatacyjnych.

Instytut Nafty i Gazu - Państwowy Instytut Badawczy

ul. Lubicz 25 A, 31-503 Kraków

E-mail: zbigniew.stepien@inig.pl 